\section{Zagorulko A., Zahorulko A., Liashenko B., Gordienko I.}

\title{
COMPARISON OF METHODS OF HEATING A ROTARY-FILM APPARATUS FOR THE PRODUCTION OF VEGETABLE CONCENTRATES
}

Об’єктом дослідження є температурне поле робочої поверхні роторно-плівкового апарату (РПА) при нагріві ніхромовою спіраллю з різним шаром теплоносія або із застосуванням гнучкого плівкового резистивного електронагрівача випромінювального типу (ГПРЕнВТ). Це пов'язано з тим, що концентрування рослинних пюре з застосуванням РПАє перспективним рішенням, за рахунок суттєвого зменшення тривалості обробки та високої якості отриманих виробів. Съогодні більшість РПА використовують електронагрів ніхромовими спіралями з проміжними теплоносіями, для забезпечення рівномірного теплового потоку, який визначається дослідним шляхом для товщини шару теплоносія в залежності від витрати сировини, що обробляється. Такі способи дозволяють отримати якісні показники рівномірності температурного поля, але проблемою є збільшення металоємності апаратів через наявність насосів для руху теплоносіїв, що в цілому призводить до ускладнення експлуатаційних умов. Тому важливим є удосконалення системи обігріву РПА із застосуванням ГПРЕнВТ, який одночасно є теплоізольованою поверхнею з рівномірним розподілом температурного поля по всій площині випромінювання. В ході дослідження визначали рівномірність розподілу температури у модельному зразку РПА при різних способах обігріву (ніхромовий дріт з проміжним теплоносієм, кремнійорганічна рідина ПФМС-4 або ГПРЕнВТ).

Отримане порівняння способів тепловідведення дозволило встановити, що обігрів ніхромовою спіраллю $\epsilon$ оптимальним при товщині шару теплоносія 4 мм з перепадом температур 1,2...2,4 ${ }^{\circ}$ C. В умовах використання ГПРЕнВТ забезпечується перепад температур: 0,5...0,7 ${ }^{\circ} \mathrm{C}$. Це підтверджує перспективність використання ГПРЕнВТ в системі обігріву РПА за умов зміни витрат сировини 0,5....1,5.103 кг/с.

Завдяки використанню ГПРЕнВТ для обігріву РПА забезпечиться поліпшення умов експлуатацї шляхом спрощення конструкщійних властивостей, зниження ресурсовитрат в порівнянні з обігрівом гріючою оболонкою з теплоносієм та оптимальним значенням перепаду температури на робочій поверхні апарата.

Ключові слова: виробництво рослинних напівфабрикатів, концентрування пюре, гнучкий плівковий резистивний електронагрівач випромінювального типу, роторний плівковий апарат.

Received date: 12.09 .2019

Accepted date: 30.09 .2019

Published date: 30.12 .2019
Copyright (C) 2019, Zagorulko A., Zahorulko A., Liashenko B., Gordienko I. This is an open access article under the CC BY license (http://creativecommons.org/licenses/by/4.0)

\section{Introduction}

One of the main operations in the production of vegetable semi-finished products is the concentration of mashed potatoes according to the technological requirements for the required dry matter content $[1,2]$. A promising heatexchange equipment in this case is rotor-film apparatuses (RFA), which are characterized by a significant reduction in processing time and high quality of the products obtained [3-5]. As well as the possibility of their direct location in lines near the places of collection of raw materials [6]. This will ensure a decrease in transportation costs, as well as preservation of the initial properties of the raw materials, which largely depend on the operating parameters of the temperature and uniformity of heating of the raw materials, necessitating the search for innovative solutions to improve the heating methods of RFA. Today, most RFAs use electric heating of nichromes with spirals with intermediate coolants to ensure uniform heat flow, which is determined empirically for the thickness of the coolant layer depending on the flow rate of the processed raw materials [7]. Such methods make it possible to obtain qualitative indicators of the uniformity of the temperature field, but are characterized by increased metal consumption of the apparatus, the presence of pumps for the movement of coolants, in general, lead to a complication of operating conditions [8]. Therefore, the engineering solution to improve the RFA heating system through the use of a flexible film resistive electric heater of the radiating type (FFREHRT), which is simultaneously a heatinsulated thermal surface with a uniform distribution of the temperature field along the entire radiation plane, is relevant [9].

Thus, the object of research is the temperature field of the RFA working surface when heated by a nichrome spiral with a different layer of coolant or FFREHRT. The aim of research is establishing the optimal temperature distribution in RFA under conditions of comparisons of the indicated methods of heat reduction depending on the consumption of raw materials. 


\section{Methods of research}

A study of the uniformity of the temperature distribution in the RFA model sample depending on the heating method is carried out by the location of thermocouples on its working surface (Fig. 1, $a$ ). RFA consists of a heat-insulated casing of apparatus 1, which is heated by FFREHRT or a nichrome spiral with an intermediate coolant (organosilicon liquid PFMS-4 [10]).

The upper part of the RFA has a separation space 3 for the removal of secondary steam. Here the apparatus is a rotary rotor 4 with hinge elements 5 . On the upper part of the rotor there is a distributor 6 for film formation of the raw material before concentration, coming through the nozzle 7 .
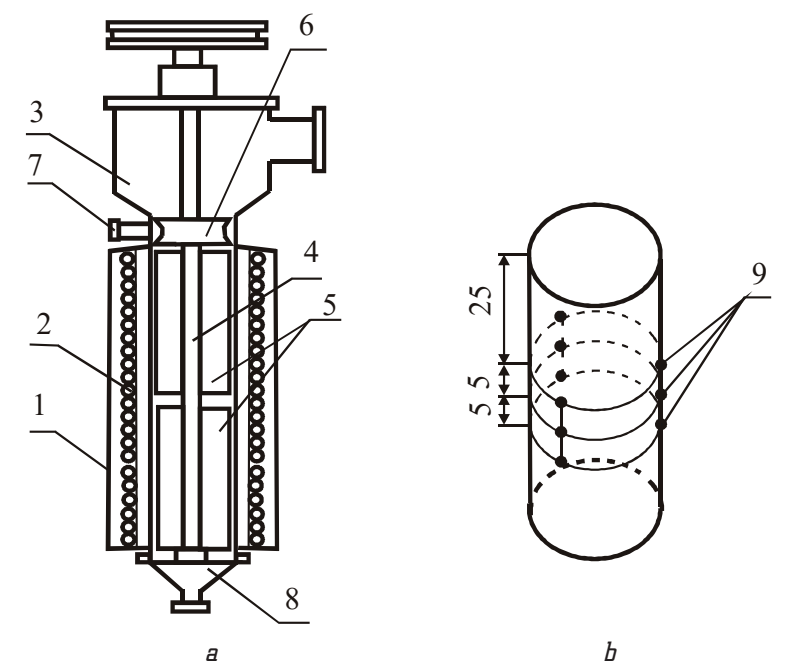

Fig. 1. Rotary film apparatus:

a - model: 1 - casing; 2 - a flexible film resistive heater of a radiating type or a nichrome spiral with a coolant; 3 - separator; 4 - rotor; 5 - film-forming elements; 6 - distributive ring; 7 - inlet pipe; 8 - output pipe; $b$ - location of thermocouples on the working surface ( 9 - thermocouples)

The lower part of the RFA is the discharge zone of the finished concentrate with nozzle 8 . The temperature of the experimental section is $25 \mathrm{~mm}$ in height from the upper edge of the loading nozzle, and its length $-10 \mathrm{~mm}$ is determined by the chromel-kopel thermocouples located on it 9 . So, to study the uniformity proposed three levels of thermocouples, three thermocouples in each (Fig. 1, $b$ ).

\section{Research results and discussion}

Experimental determination of temperature uniformity on the RFA heating surface under conditions of comparison of heating using a nichrome spiral with a different layer of intermediate coolant (PFMS-4, $\delta_{t}: 0,2,4 \mathrm{~mm}$ ) and FFREHRT. When using a nichrome spiral with a coolant with a layer thickness of $4 \mathrm{~mm}$, the temperature difference is set in the range of $1.2 \ldots 2.4{ }^{\circ} \mathrm{C}$. The thickness of the coolant 0 and $2 \mathrm{~mm}$ have a more uneven temperature distribution with a change in the flow rate of raw materials within $0.5 \ldots 1.5 \cdot 10^{3} \mathrm{~kg} / \mathrm{s}$ (Fig. 2).

Analysis of the curves $(\Delta t)$ shown in Fig. 2, confirms the optimal level of temperature difference in the range of $0.5 \ldots 0.7{ }^{\circ} \mathrm{C}$ on the working surface of the device under conditions of use in the RFA-FFREHRT heating circuit. The technical characteristics of FFREHRT make it possible to obtain a uniform distribution of the amount of heat in almost any area of the working surface. This will lead to improved operating conditions of RFA by simplifying the structural properties, reducing resource costs compared to heating a heating shell with a coolant.

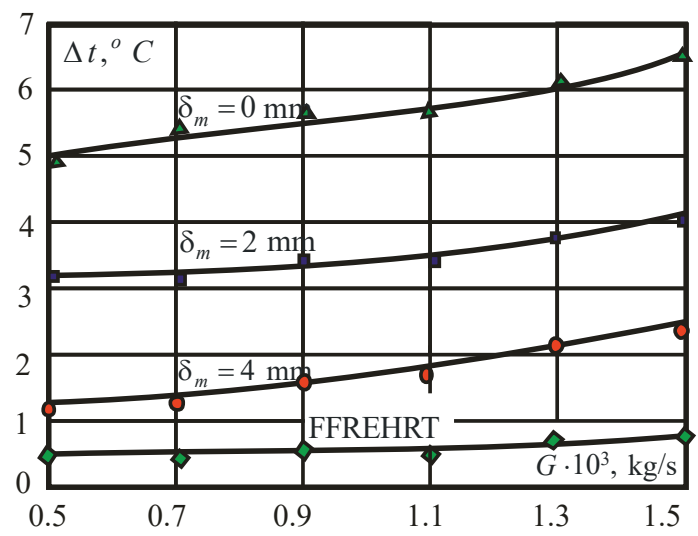

Fig. 2. The temperature difference $(\Delta t)$ of the surface of the rotor-film apparatus depending on the flow rate of the caloric fluid $G$ when heated by a flexible film resistive electric heater of the radiating type (FFREHRT) and nichrome with a coolant $\left(\delta_{t}\right)$

\section{Conclusions}

Comparison of the heat removal methods in RFA makes it possible to establish that under conditions of heating with a nichrome spiral, the optimum thickness of the coolant layer is $4 \mathrm{~mm}$ with a temperature difference of 1.2...2.4 ${ }^{\circ} \mathrm{C}$. And under conditions of using FFREHRT, a temperature difference of $0.5 \ldots 0.7{ }^{\circ} \mathrm{C}$ is provided. This confirms the promise of using FFREHRT in the RFA heating system under conditions of a change in the feed rate from $0.5 \ldots 1.5 \cdot 10^{3} \mathrm{~kg} / \mathrm{s}$.

\section{References}

1. Butko, M. P., Yasko, A. H. (2010). Rozvytok kharchovoi promyslovosti v rehionalnykh hospodarskykh systemakh Ukrainy. Ahorsvit. Ekonomika APK, 9, 2-9.

2. Cherevko, O. I., Yefremov, Yu. I., Mykhailov, V. M. (2007) Pererobka dykorosloi priano-aromatychnoi roslynnoi syrooyny. Kharkiv: KhDUKhT, 230.

3. Gaiazova, A. O., Prokhasko, L. S., Popova, M. A., Lukinykh, S. V., Asenova, B. K. (2014). Ispolzovanie vtorichnogo i rastitelnogo syria v produktakh funkcionalnogo naznacheniia. Molodoi uchenii, 19, 189-191.

4. Misra, N. N., Koubaa, M., Roohinejad, S., Juliano, P., Alpas, H., Inácio, R. S. et. al. (2017). Landmarks in the historical development of twenty first century food processing technologies. Food Research International, 97, 318-339. doi: http:// doi.org/10.1016/j.foodres.2017.05.001

5. Bucher, T., van der Horst, K., Siegrist, M. (2013). Fruit for dessert. How people compose healthier meals. Appetite, 60 , 74-80. doi: http://doi.org/10.1016/j.appet.2012.10.003

6. Telezhenko, L. N., Bezusov, A. T. (2004). Biologicheski aktionye veschestva fruktov i ovoschei: sokhranenie pri pererabotke. Odessa: Optimum, 268.

7. Cherevko, O., Mykhaylov, V., Zagorulko, A., Zahorulko, A. (2018). Improvement of a rotor film device for the production of high-quality multicomponent natural pastes. Eastern-European Journal of Enterprise Technologies, 2 (11 (92)), 11-17. doi: http:// doi.org/10.15587/1729-4061.2018.126400 
8. Hladushniak, O. K. (2015). Tekhnolohichne obladnannia konseronykh zavodiv. Kherson: Hrin D. S., 348.

9. Zahorulko, A. M., Zahorulko, O. Ye. (2016). Pat. No. 108041 UA Hnuchkyi plivkovyi rezystyonyi elektronahrivach oyprominiuiuchoho typu. MPK G05D 23/19, B01D 1/22, H05B 3/36. No. u201600827; declareted: 02.20.2016; published: 24.06.2016 Bul. No. 12, 4

10. Kremniiorhanichna ridyna PFMS-4. Available at: http://www. chemproduct.ru/shop/goods/598/

Zagorulko Aleksey, PhD, Associate Professor, Department of Processes, Devices and Automation of Food Production, Kharkiv State University of Food Technology and Trade, Ukraine, ORCID: http:// orcid.org/0000-0003-1186-3832,e-mail: zagorulko@hduht.edu.ua
Zahorulko Andreii, PhD, Associate Professor, Department of Processes, Devices and Automation of Food Production, Kharkiv State University of Food Technology and Trade, Ukraine, ORCID: http:// orcid.org/0000-0001-7768-6571,e-mail: zagorulkoAN@hduht.edu.ua

Liashenko Bogdan, PhD, Associate Professor, Department of Processes, Devices and Automation of Food Production, Kharkiv State University of Food Technology and Trade, Ukraine, ORCID: http:// orcid.org/0000-0001-7228-8814

Gordienko Iryna, Postgraduate Student, Department of Processes, Devices and Automation of Food Production, Kharkiv State University of Food Technology and Trade, Ukraine, ORCID: http:// orcid.org/0000-0002-2274-7565

\section{Sytnik N., Mazaeva V., Bilous O., Bukhkalo S., Glukhykh V., Sabadosh G., Natarov V., Yarmysh N., Kravchenko T., Zakharkiv $\mathbf{S}$.}

\section{RESEARCH OF OXIDATIVE STABILITY OF VEGETABLE OILS FOR USE IN SPORT NUTRITION}

Об’єктом дослідження є соняшникова, соняшникова високоолеїнова та ріпакова олї, які є важливими у виробнищтві продуктів харчування для людей з підвищеними фізичними навантаженнями. Такі продукти мають бути збалансовані за компонентним складом та збагачені біологічно активними речовинами, вітамінами, антиоксидантами. Олї та жири використовують як важливий компонент спортивного харчування. Розповсюдженою олією є соняшникова олія, яка забезпечує раціон лінолевою кислотою, а також ріпакова олія, яка збагачує продукти ліноленовою кислотою. Одним з найбільш проблемних місиь використання олій є окиснювальне псування, оскільки це призводить до утворення небезпечних для здоров'я сполук. В ході дослідження використовувалися метод активного кисню та прилад Охіtеst (Iталія). Перший метод дозволяє безпосередньо очінювати вміст продуктів окиснення в олії через значення пероксидного числа, другий метод дозволяє вимірювати витрату кисню під час процесів окиснення в оліі.

Проведено дослідження окиснювальної стабільності олї соняиникової методом активного кисню та методом окиснення з використанням приладу Oxitest за температури $110{ }^{\circ} \mathrm{C}$. Встановлено, що періоди індукщї, визначені двома методами, є близькими (2 год. 40 хв. та 2 год. 43 хв., відповідно). Встановлено закономірність зниження періоду індукиї олії соняшникової під час підвищення температури методом окиснення на приладi Oxitest. Використано температури 90, 100 та $110{ }^{\circ} \mathrm{C}$. Виконано порівняльне дослідження окиснювальної стабільності соняшникової, соняшникової високоолеїнової та ріпакової олій. На підставі одержаних даних наведено порівняльну характеристику стійкості дослідних олій до окиснення та надано рекомендащї для їх використання у спортивному харчуванні. Одержані дані дозволять оцінювати вплив кожної з дослідних олій на строк придатності олієвмісного продукту.

Ключові слова: спортивне харчування, олія соняшникова, олія ріпакова, окиснювальна стабільність, період індукиї.

\section{Introduction}

Current nutritional requirements require the consumption of polyunsaturated fatty acids, essential amino acids and minerals in sufficient quantities. But usually modern nutrition does not fully satisfy the need for such important components [1,2]
A particularly acute issue of good nutrition is relatively certain categories of the population, in particular, people who engage in sports activities. Preparation for the competition, daily training, high psychological endurance require special nutrition, which will contribute to high endurance and quick recovery [3-5]. In order to meet the needs of the body of a person involved in sports, special 